\title{
Sinopharm! An Unavoidable Contender in the Struggle Against COVID [Letter]
}

\author{
Syed Hasan Shuja (D) \\ Dayab Asad ${ }^{2}$ \\ Abdul Samad Parekh ${ }^{3}$ \\ 'Dow Medical College, Karachi, Sindh, \\ Pakistan; ${ }^{2}$ Jinnah Sindh Medical University, \\ Karachi, Sindh, Pakistan; ${ }^{3}$ Shaheed \\ Mohtarma Benazir Bhutto Medical \\ College, Karachi, Sindh, Pakistan
}

Correspondence: Syed Hasan Shuja Dow Medical College, Dow University of Health Sciences, Baba-e-Urdu Road, Karachi, 74200, Pakistan

Tel +923200250770

Email hasanshuja6@gmail.com

\section{Dear editor}

We recently came across a review "Overview of the Main Anti-SARS-CoV-2 vaccines: Mechanism of Action, Efficacy and Safety" published by Mescellino MT et al in the reputable journal "Infection and drug resistance." ${ }^{11}$ We would like to appreciate the authors for their efforts and would like to congratulate them on a successful publication.

The review discussed the steps for the preparation, storage, efficacy, mechanism of action, and safety of five of the most commonly administered vaccines, namely PfizerBioNTech, Moderna, Astra-Zeneca Oxford, Sputnik V, Janssen (Johnson \& Johnson). Moreover, the authors also analyzed the effect of these vaccines against the different variants of COVID-19 particularly the Delta Variant and the new vaccines, which are currently in trial phases and can prove to be interesting prospects. ${ }^{1}$ Although the review is very comprehensive with detailed coverage of the above-mentioned aspects, we feel that the review has certain lackings as it failed to mention the role of the Sinopharm vaccine and booster shots in the fight against Covid-19.

Sinopharm COVID-19 BBIP-CorV, developed by Sinopharm and the Beijing Institute of Biological Products Co., is an inactivated vaccine. It works by exposing the immune system to the inactivated (incapable of disease-producing) virus particulate which leads to the development of antibodies against the virus. ${ }^{2}$ This vaccine is administered intramuscularly in two dosages with a break of at least three weeks between each dose and has proven to be $79 \%$ effective in preventing symptomatic infection and hospitalization of SARS-CoV-2. ${ }^{3}$ Possible side effects of this vaccine include pain at the injection site, fatigue, headache, lethargy post each dose. ${ }^{2}$

Moreover, the virus is constantly evolving, and researchers are uncertain whether the current vaccines are effective against the new strains. As such, booster shot programs are set to begin in the fall this year if approved by the Food and Drug Administration. A booster shot refers to an additional shot that is given to vaccinated individuals with diminishing immunity in order to enhance the protection This shot is administered after a gap of six to eight months. ${ }^{4}$

As Sinopharm vaccine is the fifth most administered vaccine with 2.09 million doses being administered as of September $2021,{ }^{5}$ we feel that not including the vaccine in the review can evoke panic amongst the recipients as it can make them doubt the effectiveness of the vaccine and can create a sense of insecurity in them. Furthermore, people also need to be made aware of the booster shot programs so that they are prepared for it and the process could take place efficiently. 


\section{Disclosure}

The authors report no conflicts of interest for this communication.

\section{References}

1. Mascellino MT, Timoteo FD, Angelis MD, Oliva A. Overview of the Main Anti-SARS-CoV-2 vaccines: mechanism of action, efficacy and safety. Infect Drug Resist. 2021;14:3459-3476. doi:10.2147/IDR.S315727

2. Sinopharm COVID-19 Vaccine (BBIBP-CorV) - precision Vaccinations. Available from: https://www.precisionvaccinations.com/vaccines/sino pharm-covid-19-vaccine-bbibp-corv. Accessed September 9, 2021.
3. The Sinopharm COVID-19 vaccine: what you need to know. Available from: https://www.who.int/news-room/feature-stories /detail/the-sinopharm-covid-19-vaccine-what-you-need-to-know. Accessed September 9, 2021.

4. COVID-19 Vaccine Booster Shot | CDC. Available from: https:// www.cdc.gov/coronavirus/2019-ncov/vaccines/booster-shot.html. Accessed September 9, 2021.

5. COVID-19 vaccine doses administered by manufacturer, European Union. Available from: https://ourworldindata.org/grapher/covidvaccine-doses-by-manufacturer?country= European+Union. Accessed September 9, 2021.

Dove Medical Press encourages responsible, free and frank academic debate. The content of the Infection and Drug Resistance 'letters to the editor' section does not necessarily represent the views of Dove Medical Press, its officers, agents, employees, related entities or the Infection and Drug Resistance editors. While all reasonable steps have been taken to confirm the content of each letter, Dove Medical Press accepts no liability in respect of the content of any letter, nor is it responsible for the content and accuracy of any letter to the editor.

\section{Publish your work in this journal}

Infection and Drug Resistance is an international, peer-reviewed openaccess journal that focuses on the optimal treatment of infection (bacterial, fungal and viral) and the development and institution of preventive strategies to minimize the development and spread of resistance. The journal is specifically concerned with the epidemiology of

Submit your manuscript here: https://www.dovepress.com/infection-and-drug-resistance-journal antibiotic resistance and the mechanisms of resistance development and diffusion in both hospitals and the community. The manuscript management system is completely online and includes a very quick and fair peerreview system, which is all easy to use. Visit http://www.dovepress.com/ testimonials.php to read real quotes from published authors. 